\title{
ETYMOLOGICAL ASPECTS OF DEVELOPING FUTURE PHYSICIANS' TERMINOLOGICAL COMPETENCE AS A PEDAGOGICAL PROBLEM
}

\author{
Г. Б. Паласюк, О. Д. Колодницька \\ Тернопільський національний медичний університет імені І. Я. Горбачевського МОЗ Украӥни

\section{ЕТИМОЛОГІЧНІ АСПЕКТИ ФОРМУВАННЯ ТЕРМІНОЛОГІЧНОЇ КОМПЕТЕНТНОСТІ МАЙБУТНІХ ФАХІВЦІВ ІЗ МЕДИЦИНИ ЯК ПЕДАГОГІЧНА ПРОБЛЕМА}

\begin{abstract}
Many medical terms have been replaced by descriptive names taken from everyday vocabulary, ancient mythology, etc. due to the lack of an appropriate term reflecting a body organ or a disease in ancient times.

Knowing the etymology of the medical terms contributes to their deeper and better understanding, memorizing and practical use by highly qualified future physicians. All of these issues prompted us to write the article.

Latin was the international language of medicine until the $18^{\text {th }}$ century. Greek terms were created at the times of Hippocrates, Galen and their precursors. Aul Cornelius Celsus established the basis of Latin medical terminology as well as Latin terms were created in the Middle Ages. Most of the Greek terms were Latinized. Modern European languages vocabulary gradually penetrated into medical terminology only in the $19^{\text {th }}$ century.

Much of the medical vocabulary consists of the names due to metaphorization phenomenon of common names, and the names of household items. Such names can be subdivided into three groups according to a theory of nomination. The first group includes lexemes according to the association in appearance, e.g., membrana arachnoidea (derives from Geek $\alpha \rho \alpha \chi v \eta$ (arachne, es $f$-a "spider")) has English equivalent the "arachnoid membrane" of the brain. The second group covers terms due to functional similarity, e.g., incus, $\bar{u}$ dis $f$ denoting an "anvil" or "incus" (one of the auditory ossicles contained in the tympanic cavity) resembling the anvil used in blacksmithing. Both terms according to the association in appearance and functional similarity belong to the third group, e.g., pelvis, is $f$ denotes a "basin" or "container" in colloquial language and it means a "pelvis" in anatomy, e.g, pelvis minor - the "lesser or true pelvis", pelvis maior - the "greater pelvis".

The prospects of further research are in the study of mythonyms and eponyms according to the great importance of developing future physicians' terminological competence and clinical thinking.

Key words: term; metaphorization phenomenon; Greek; Latin; future physician; terminological competence.

Анотація. Серед медичних термінів є немало таких, які через відсутність на той час відповідного кваліфікаційного терміна, який міг би відобразити орган тіла чи певне захворювання, замінювались описовими назвами, взятими із побутової лексики, античної міфології тощо. У цьому аспекті важливу роль відіграє знання і розуміння етимології медичних термінів майбутніми висококваліфікованими лікарями, що й спонукало нас до написання статті.

Латинська мова була міжнародною мовою медицини аж до XVIII ст. Основу медичної термінології становлять грецькі терміни часів Гіппократа, Галена та їх попередників і латинські терміни, створені у середні віки та в часи Авла Корнелія Цельса. Увійшовши до медичної латинської мови, більшість грецьких термінів латинізувалась. І лише у ХІХ ст. у медичну термінологію починають поступово проникати слова із сучасних європейських мов.

Значну частину лексики медичної термінології складають вторинні назви, які виникли в процесі метафоризації загальновживаних слів, зокрема назв предметів побуту. Відповідно до теорії номінації такі найменування можна умовно поділити на три групи: 1) лексеми, які утворилися внаслідок асоціації за зовнішньою подібністю, наприклад: membrane arachnoidea - павутиноподібна оболона мозку, походить від грецького слова arachne, esf - павук, оскільки є настільки тонкою, що своїм виглядом нагадує павутину; 2) терміни, які утворилися в результаті функціональної подібності, наприклад: incus, $\bar{u} d i s f$ (коваделко, одна із слухових кісточок у барабанній порожнині вуха через подібність до ковадла, яке колись використовували у
\end{abstract}

(C) H. B. Palasiuk, O. D. Kolodnytska 


\section{Materials of International Scientific and Practical Conference \\ “PROFESSIONAL AND COMMUNICATION CULTURE OF THE FUTURE DOCTOR: LINGUISTIC, PEDAGOGICAL AND PHILOSOPHICAL ASPECTS”}

ковальстві); 3) терміни, які утворилися як за функціональною, так і за зовнішньою подібністю, наприклад: pelvis, isf - ємність, таз у розмовній мові, а в анатомічній термінології - таз (pelvisminor - малий таз, pelvismaior - великий таз).

3 огляду на важливість формування термінологічної компетентності для формування клінічного мислення майбутніх медиків перспективи подальших досліджень вбачаємо у вивченні назв із епонімічним та міфонімічним ономастичним компонентом.

Ключові слова: термін; процес метафоризації; грецька мова; латинська мова; майбутній фахівець із медицини; термінологічна компетентність.

Introduction. Scientific terminology plays an important role in every branch of knowledge. Its significance is particularly important for a large number of medical scientific terms requiring orthographic literacy. The highly qualified physicians' training includes the terminological training either at the level of understanding and the ability to use medical terms professionally in practical or scientific activity, both in oral and written forms [2].

All aspects of modern medical terminology are the result of its development and improvement over millennia. In our judgement, the G. Lang's statement is quite right: "Names of diseases created by the human mind have gradually changed, disappeared, re-created over millennia, etc. They reflected the corresponding periods of development of medical knowledge over time" [4]. There are many medical terms that have been replaced by descriptive names taken from everyday vocabulary, ancient mythology, etc. due to the lack of an appropriate term reflecting a body organ or a disease in the ancient times. Knowing the etymology (aetimologia from Greek etymon - a "true, real, actual origin", "the true sense of a word according to its origin" and logos - a "word", a "study") of the medical terms contributes to their deeper and better understanding, memorizing and practical use by the highly qualified future physicians.

The aim - to elucidate the etymology of some anatomical and clinical terms.

Theoretical framework. Latin terms or lexical elements of Greek and Latin origin are used in modern medicine. Latin was the international language of medicine in the Middle Ages and retained its importance until the 18th century. Greek terms were created at the times of Hippocrates (46-377 years BC), Galen (131-201 years BC) and their precursors, and Latin terms were created at the times of Aul Cornelius Celsus (30-50 years BC), the Roman encyclopedist, the author of "De medicina", and in the Middle Ages. He established the basis of medical terminology. New terms are being created with the development of medicine, but exclusively based on Greek and Latin. The ancient Greeks used common names as the terms by giving them additional meaning. There were also specific names for some diseases and symptoms that are considered to be the first patterns of term formation, e.g. herpes, coma, epidemia, nosos, cholěra, erythema, etc. Most of the Greek terms were Latinized entering the Latin medical terminology, which reflected on their transcription and pronunciation. Modern European languages vocabulary gradually penetrated into medical terminology only in the XIX century.

Word "term" (derives from Latin "terminus" - a "border" or "boundary"; in Roman religion, Terminus was the god who protected boundary markers) is a word or word combination which clearly expresses a specific concept in a particular branch of science or other types of human activity.

Much of the medical vocabulary consists of the names due to metaphorization phenomenon of common names, in particular, the names of household items. Czech scientists M. Dokulil and J. M. Dokulil and J. Kukharz [5] developed a theory of nomination, according to which such names can be subdivided into three groups. The first group includes lexemes according to the association in appearance. The second group covers terms due to functional similarity. Both terms according to the association in appearance and functional similarity belong to the third group.

Latin term ampulla, ae $f$ means an "ampulle", a "vial" or "a small round bottle with two handles" in common language [1], and belongs to the first group. It denotes "a dilated portion of various tubular organs" in medical terminology, e.g., ampulla recti - an "ampulla of the rectum". Also, for instance, a Latin noun falx, falcis $f$ means a "sickle" or "scythe" in common language [1], but it indicates "the falciform process of dura mater" in medical terminology. Latin falx cerebi is a sickle-shaped fold of dura mater located at the midline between the two cerebral hemispheres, named due to its shape. Latin noun lens, lentis $f$ and Greek noun phakos had meaning "lentil” in classical languages. Later, scientific terminology used these words to refer to a "lens" that is in the form similar to lentil grain. Latin noun trachea, ae $f$, colloquially called the windpipe, is a cartilaginous tube between the larynx and the bronchi due to its rough surface in medicine (e. g., Latin tracheia arteria literally means a "rough artery"and derives from Greek trachys - "rough”). Latin noun atrium, 
i $n$ derives from Latin adjective ater, $a$, um denoting "black, dark, gloomy". It means the central part of the Roman house in ancient Rome, but it denotes a "lobby" in medical terminology, e.g., Latin atrium cordis denotes an "atrium of heart". Arachnoid membrane of the brain (Latin equivalent is membrana arachnoidea) derives from Geek $\alpha \rho \alpha \chi v \eta$ (arachne, es $f-$ a "spider"). It lies between the hard (dura mater) and soft (pia mater) membranes and is so thin resembling a spider's web.The cup-shaped socket of the hip joint, borrowed from Latin acetabulum, i $n$, literally means a "little vinegar cup". It is the deep cuplike cavity on the side of the hipbone that receives the head of the thighbone. Clavicula (Latin clavicula, ae $f$ - "small key", because the bone resembles a long-bent key) is a paired bone, located above the first rib resembling an elongated letter "S".

The names of glands of internal secretions, such as epiphysis, pituitary, thyroid, and parathyroid glands, adrenal glands, hypothalamus, pancreas, thymus (thymus), etc. have very interesting etymology.

Term "gland" in Latin glandula, ae $f$ derives from Latin glans, glandis $f$ - an "acorn”, a "nut”; "any acorn-shaped fruit". The size and shape of an acorns fit to their similar forms. Pineal body (Latin glandula pinealis) derives from Latin pinea, ae f-a "pine cone". This term has the synonym epiphysis cerebri. A Greek word “epiphysis" denotes the "growth" (Greek prefix epi- indicates the position above something, word termination -physis means "nature”, "origin”).

The expression glandula pituitaria - the "pituitary gland" derives from Latin pituita, ae f- "mucus", "phlegm". It was named the "pituitary gland" due to the thought that the gland was sending mucus to the nose. This term, like epiphysis, has the Greek synonym "hypophysis" denoting a "process" (Greek prefix hypomeans "beneath, below, under" and word termination physis denotes a "nature" or "origin"). The expression glandula thyreoidea means a "thyroid gland" indicating a similarity to the shield (Greek thyreos - a "shield").

There are many such terms in clinical terminology (Greek klinikos- "pertaining to a bed"). The clinical term ascites, ae $m$ derives from Greek askites meaning a "bag”, "bladder", or "belly". There are such English equivalents in medical terminology as "ascites", "an accumulation of fluid in the peritoneal cavity", an "abdominal dropsy" as the accumulation of transudate in the abdominal cavity resembling an inflated bag.

Carbuncle derives from Latin noun carbo, ōnis $f$ "coal" or "charcoal". Latin equivalent of "carbuncle" is carbuncǔlus, i m. It is a dark-red, swollen, and painful cluster of boils that are connected to each other under the skin. A boil (or furuncle) is an infection of a hair follicle that has a small collection of pus (called an abscess) under the skin. The name is associated with a charcoal-like colour.

Many anatomical terms have been named due to their resemblance to certain animals. For instance, coccyx, igis $f$ means a "cuckoo" in colloquial language, and it denotes a "coccyx" or "tail bone" in anatomical terminology because of its similarity to the cuckoo beak. Latin noun cochlea, ae $f$ denotes a "seashell" in colloquial language, but it means a "cochlea" or "pinna" (inner ear) in medicine. The names of some diseases or their symptoms also include word-terminations derived from the names of animals, e.g., buphthalmus, i m meansan "ox-eye"; the "ox-eyed" (Greekbus - an "ox" and ophthalmus - an "eye"; lagophthalmus, i m denotes a "hare eye", "an inability to close the eye or eyelid"(Greek lagos u - a "hare" and ophthalmus an "eye"); lagostoma (syn. labium leporinum) means a "hare lip" (Greek lagos - a "hare "and stoma - a "mouth" or an "orifice". Clinical term elephantiasis, is $f$ (Greek elephant - an "elephant" and -iasis - a "pathological or morbid condition") is a condition characterized by gross enlargement of an area of the body, especially the limbs resembling elephants' ones. Other areas commonly affected include the external genitals. Elephantiasis is caused by obstruction of the lymphatic system, which results in the accumulation of a fluid called lymph in the affected areas. Clinical term leontiasis, is f has English equivalent "leontiasis", a "lion face"(Greek leont- (leon, leontos - a "lion") and word termination-iasis means a "pathological or morbid condition") is a rare medical condition, characterized by an overgrowth of the facial and cranial bones resulting in a lion like appearance.

Clinical terms created on the basis of color associations are widely used in modern medicine. For instance, melanoma (Greek melan - "dark”, "black”, and -omaa "tumour"), also known as malignant melanoma, is a type of cancer that develops from the pigment-producing cells known as melanocytes; xanthoma (Greek xanthos- "yellow", "yellowish") is fibroma with a yellowish colour; leukoma (Greek leukos - "white") is a dense white opacity in the cornea of the eye.

Clinical terms related to colour perception are used in ophthalmology. All these terms are made due to a sample - a word termination denoting "colour" + “-opsia” (Greek ópsis - a "vision”), e.g.: chloropsia 


\section{Materials of International Scientific and Practical Conference \\ "PROFESSIONAL AND COMMUNICATION CULTURE OF THE FUTURE DOCTOR: LINGUISTIC, PEDAGOGICAL AND PHILOSOPHICAL ASPECTS”}

(Greek chlorós, chlor- - "green”) - a visual defect in which all objects appear green; xanthopsia (Greek xanthos, xanth- - "yellow”, "yellowish”) is a visual defect in which all objects appear yellow; cyanopsia (Greek cyan- - "blue") is a visual defect in which all objects appear blue; erythropsia (Greek erythr- - "red") is a visual defect in which all objects appear red. Ophthalmic term iris, idis $f$ means the pigmented muscular curtain near the front of the eye, between the cornea and the lens, that is perforated by an opening called the pupil. It also has a metaphorical origin denoting "rainbow" in Greek. Iris was the name of the Greek goddess of the rainbow, also serving as a messenger to the gods.

Dermatological terms indicating the skin (Greek derma - the "skin") colour changes, e.g., cyanodermia means bluishness, xanthodermia is the yellow colour of the skin, erythroderma denotes the red colour of the skin, melanodermia is darkening of the skin, leukoderma means white spots on the skin.

There are also clinical terms made due to the association on the basis of metaphorization. For instance, term anthrax - "anthrax" (Greek anthrax "coal”, "charcoal”) is a rare but serious illness caused by a spore-forming bacterium, Bacillus anthracis. The semantics of colour is the basis of this metaphor because the scab of anthrax has a charcoal black colour. Icterus is a Latinized (-us) form of the Greek word "ikteros" denoting both "jaundice" and a "yellow bird". It was thought that jaundice could be cured if the patient gazed at the bird. The disease would transmigrate from the jaundiced patient to the hapless bird.

The second group covers terms due to functional similarity, e.g., thorax, acis $m$ denoting a "thorax armour or chest armour” (Greek thoresso - "to arm”). It means a "chest" or "thorax" in the medical terminology and it is the part of the body of a mammal between the neck and the abdomen, including the cavity enclosed by the ribs, breastbone, and dorsal vertebrae, and containing the chief organs of circulation and respiration.

Latin noun tubŭlus, i $m$ denotes a "small tube", a "tubule" or a "minute tubular structure" in colloquial language. It means "canal” in anatomical terminology [1], e.g., tubŭlus renalis contortushas English equivalenta "contort renal tubule".

One of the auditory ossicles contained in the tympanic cavity was named incus, ūdis $f$ - an "anvil” or "incus" resembling the anvil used in blacksmithing. Latin noun vas, vasis $n$ can be assigned to this group of names. It has the colloquial meaning "a hollow con- tainer" in the singular form, and "household utensils" in the plural one. Latin noun vas, vasis $n$ has English equivalent a "vessel" in anatomical terminology, i.e., a duct or canal holding or conveying blood or other fluid, e.g., vasa cordis - "vessels of the heart".

A huge quantity of vocabulary composes anatomical terms according to the association in appearance and functional similarity. For instance, Latin noun cisterna, ae $f$ has the colloquial meaning a "box" or a "reservoir" [1]. The Latin word combination cisterna subarachnoidalis means a "subarachnoid cistern" in medical nomenclature. The subarachnoid cisterns are spaces formed by openings in the subarachnoid space separating the two meninges, the arachnoid mother and the pia mater. These cisterns are filled with cerebrospinal fluid resembling tanks due to their appearance and functional purpose.

Latin noun bursa, ae $f$ has the colloquial meaning a "pocket". It means a "bursa", "pouch", "sac", or "vesicle" in medical terminology [4], e.g., bursa omentalis - the "omental bursa", and bursa hepatica - the "hepatic bursa”).

Latin noun pelvis, is $f$ denotes a "basin" or "container" in colloquial language. It means a "pelvis" in anatomy, e.g, pelvis minor - the "lesser or true pelvis", pelvis maior - the "greater pelvis". The anatomical term "pelvis" denotes the basin-shaped complex of bones that connects the trunk and the legs, maintains and balances the trunk, and contains and supports the intestines, the urinary bladder, and the internal sex organs.

Latin noun paries, etis $m$ - a "wall” also belongs to the third group [3]. This term is used approximately 20 times in different chapters of anatomy. For instance, paries cavitatis abdominis anterior - the "anterior wall of the abdominal cavity"; paries inferior cavitatis nasi - the "inferior wall of the nasal cavity"; paries membranaceus cavitatis tympani - the "membranous wall of the tympanic cavity”, etc.

Conclusions and Prospects for Research. Thus, the etymology of medical terms is closely related to the metaphorization phenomenon due to the conducted research. Functional similarity, the similarity in appearance, or analytical similarity, i.e., both similarity in appearance and in functions simultaneously, are mostly the background for the choice of a particular language form.

The prospects of further research are in the study of mythonyms and eponyms according to the great importance of developing future physicians' terminological competence and clinical thinking. 


\section{Materials of International Scientific and Practical Conference \\ "PROFESSIONAL AND COMMUNICATION CULTURE OF THE FUTURE DOCTOR: \\ LINGUISTIC, PEDAGOGICAL AND PHILOSOPHICAL ASPECTS”}

\section{List of literature}

1. Дворецкий И. Х. Латинско-русский словарь / И. Х. Дворецкий. - 11-е изд., стереотип. - М. : Русский язык - Медиа, 2008. - 843 с.

2. Закалюжний М. М. Клінічна латина з англійськими та українськими відповідниками / М. Закалюжний, М. Андрейчин, Р. Комаровський. - Тернопіль : ТДМУ, 2017. - 832 с.

\section{References}

1. Dvoretskiy, I.H. (2008). Latinsko-russkiy slovar [LatinRussian dictionary]. Moscow: Russkiy yazyik. Media [in Russian].

2. Zakaliuzhnyi, M., Andreichyn, M., \& Komarovskyi, P. (2017). Klinichna latyna z anhliiskymy ta ukrainskymy vidpovidnykamy [Latin clinical terminology with English and Ukrainian correspondences]. Ternopil: TSMU [in Ukrainian].
3. Міжнародна анатомічна номенклатура / за ред. I. І. Бобрика, В. Г. Ковешнікова. - К. : Здоров'я, 2001. - 328 с.

4. Энциклопедический словарь медицинских терминов : в 3-х т. - М., 1984. - Т. 3. - 512 с.

5. Dokulil M. Tvoření slovv češtině / M. Dokulil // Teorieodvozování slov. - Praha : Naklad, 1962. - 264 p.

3. Bobryk, I.I., \& Koveshnikov, V.H. (2001). Mizhnarodna anatomichna nomenklatura [International anatomical nomenclature]. Kyiv: Zdorovia [in Ukrainian].

4. Petrovsky, B.V. (1984). Entsiklopedicheskiy slovar meditsinskikh terminov [Encyclopedic dictionary of medical terms]. Moscow; Vol. 3 [in Russian].

5. Dokulil, M. (1962). Tvoření slov v češtině. Teorie odvozování slov. Prague: Naklad.

E-mail address for correspondence: kolodnytska_ol@tdmu.edu.ua 